\title{
Agronomic biofortification with zinc in curly lettuce cultivars
}

\author{
Patricia Diniz Graciano ${ }^{1} \oplus$, Ana Carolina Pires Jacinto ${ }^{1} \oplus$, Aline José da Silveira ${ }^{2}{ }^{\circ}$,

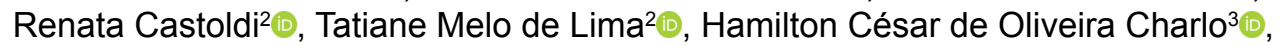 \\ Isadora Gonçalves da Silva ${ }^{1} \odot$, Marcus Vinícius Marin ${ }^{4} \odot$

\footnotetext{
1 Universidade Federal de Uberlândia, Uberlândia, MG, Brasil. E-mail: patriciagraciano01@hotmail.com; carol.agro.ufu@gmail.com; isadoragsilva@live.com

2 Universidade Federal de Uberlândia, Monte Carmelo, MG, Brasil. E-mail: alinejoseagro@gmail.com; rcastoldi@ufu.br; lima.tm@ufu.br

${ }^{3}$ Instituto Federal de Educação, Ciência e Tecnologia do Triângulo Mineiro, Uberaba, MG, Brasil. E-mail: hamiltoncharlo@iftm.edu.br

4 University of Florida, Gainesville, FL, United States of America. E-mail: marcusvmarin@gmail.com
}

ABSTRACT: In underdeveloped countries, zinc deficiency is a public health problem. The main foods consumed in these countries have low levels of the nutrient, making their consumption insufficient to meet the minimum daily requirements. Therefore, the aim of this study was to evaluate agronomic biofortification with zinc in curly lettuce cultivars. The experiment was carried out at the Universidade Federal de Uberlândia - Monte Carmelo Campus, using a complete randomized block design in a $4 \times 5$ factorial scheme with four replications. The factors consisted of four curly lettuce cultivars (Brida, Isabela, Thaís, and Vanda) and five doses of leaf zinc $\left(0,400,800,1200\right.$ and $1600 \mathrm{~g} \mathrm{ha}^{-1}$ of $\left.\mathrm{Zn}\right)$. The following traits were evaluated: zinc leaf content, plant height, SPAD index, total fresh mass, stem diameter, head diameter, number of leaves per plant, and estimated average yield. Data were subjected to analysis of variance by the $F$ test $(\alpha=0.05)$ and means were compared by Tukey test at $5 \%$ probability and regression analyzes. According to the results obtained, the cultivar Thais can be considered the lettuce with highest leaf zinc content and the most biofortified. It is advisable to use $700 \mathrm{~g} \mathrm{ha}^{-1}$ of leaf zinc to obtain biofortified lettuce with increased yield.

\section{Biofortificação agronômica com zinco em cultivares de alface crespa}

RESUMO: Em países subdesenvolvidos, a deficiência de zinco é um problema de saúde pública. Os principais alimentos consumidos nesses países apresentam baixos teores do nutriente, tornando seu consumo insuficiente para atender aos requerimentos mínimos diários. Diante disso, objetivou-se avaliar a biofortificação agronômica com zinco, em cultivares de alface crespa. $O$ experimento foi realizado na Universidade Federal de Uberlândia - Campus Monte Carmelo, utilizando delineamento de blocos casualizados, em esquema fatorial $4 \times 5 \mathrm{com}$ quatro repetições. Os fatores consistiram em quatro cultivares de alface crespa (Brida, Isabela, Thaís e Vanda) e cinco doses de zinco foliar (0, 400, 800, 1200 e $\left.1600 \mathrm{~g} \mathrm{ha}^{-1}\right)$. Avaliaram-se os seguintes caracteres: teor foliar de zinco, altura de planta, índice SPAD, massa fresca total, diâmetro do caule, diâmetro da cabeça, número de folhas por planta e produtividade média estimada. Os dados foram submetidos à análise de variância, pelo teste $F(\alpha=0,05)$ e as médias foram comparadas pelo teste Tukey a $5 \%$ de probabilidade e análises de regressão. De acordo com os resultados obtidos, a cultivar Thaís destacou-se por acumular o maior teor de zinco na folha. É recomendável o uso de $700 \mathrm{~g} \mathrm{ha}^{-1}$ de zinco via foliar para obter alface biofortificada com maior produtividade.

Palavras-chave: aplicação via foliar; Lactuca sativa; nutrição de planta; doses de zinco 


\section{Introduction}

Zinc deficiency affects approximately one third of the world's population, accounting for about 16, 18 and $10 \%$ of respiratory infections, malaria rates and diarrhea, respectively (Rios et al., 2009). Zinc is essential for humans because it is related to immune system functioning, sensory function, neurobehavioral development, reproductive health, growth, and physical development (Hotz \& Brown, 2004). In underdeveloped countries, zinc, iron, and vitamin A deficiencies are considered public health problems.

Despite their importance in human health, the main foods consumed in developing countries have low micronutrient levels, making their consumption insufficient to meet the minimum daily requirements (Carvalho \& Vasconcelos, 2013). Therefore, some methods are being used to attend the need of zinc in humans is supplied (Cakmak, 2008), highlighting among them the agronomic biofortification, which aims to enrich the food through fertilization (Cakmak et al., 2010; Hussain et al., 2012) via soil and / or leaf. Both forms of zinc application have shown satisfactory results regarding their elevation in cereal grains (Cakmak, 2009; Hussain et al., 2012), beans (Cambraia, 2015) and onion (Almendros et al., 2015). However, there is still little research related to agronomic biofortification in leafy vegetables.

Lettuce (Lactuca sativa L.) is the most consumed leafy vegetable in the world, being considered of great nutritional importance, providing considerable contents of phosphorus $\left(20 \mathrm{mg}^{100 \mathrm{~g}^{-1}}\right)$, potassium (141 mg 100g $\left.{ }^{-1}\right)$, vitamin C (2.8 mg $\left.100 \mathrm{~g}^{-1}\right)$, and vitamin $\mathrm{A}\left(25 \mu \mathrm{g} 100 \mathrm{~g}^{-1}\right)$ as well as being a source of fiber and low in calories (USDA, 2019). However, humans need about 22 nutrients to maintain their proper and healthy metabolism (Graham et al., 2007), and some of these are not present or present in low levels in lettuce leaves. Among these nutrients present in low amounts is zinc (Zn), a micronutrient with daily requirements of about $11 \mathrm{mg}$ for adults $(\mathrm{NIH}, 2020)$.

Because lettuce is a vegetable that is increasingly present in several dishes, and is easy to prepare and low cost, any strategy aimed at enhancing agronomic biofortification can result in several health benefits. Biofortification of lettuce cultivars with zinc may contribute to supply nutritional deficiencies of low-income populations, as it presents itself as an affordable and easily produced food. Therefore, the aim of this study was to evaluate the agronomic biofortification with zinc in curly lettuce cultivars.

\section{Materials and Methods}

The experiment was carried out from March 05 to June 09, 2018, in Monte Carmelo-MG, belonging to the Universidade Federal de Uberlândia (altitude 873 m, 1843'37" S and 47 - $31^{\prime} 27^{\prime \prime}$ W). The climate, according to the Köppen climate classification, is humid temperate, with hot summers and dry winters.

A randomized complete block design in a $4 \times 5$ factorial scheme with four replications was used. The treatments resulted from the combination of four curly lettuce cultivars (Brida, Isabela, Thaís, and Vanda) and five doses of zinc applied via foliar (0, 400, 800, 1200 and $\left.1600 \mathrm{~g} \mathrm{ha}^{-1}\right)$, using as source zinc sulfate PA with $20 \%$ zinc. Each experimental plot consisted of four planting lines, containing 20 plants per plot, arranged in a spacing of $0.25 \mathrm{~m}$ between rows and $0.25 \mathrm{~m}$ between plants $\left(1.25 \mathrm{~m}^{2}\right.$ plot $\left.^{-1}\right)$ of each plot.

Sowing was carried out on March 5, 2018, in 200-cell polyethylene trays filled with commercial coconut shell fiberbased substrate. Prior setting up the experiment, soil was sampled at a depth of 0 to $20 \mathrm{~cm}$ for chemical and physical analysis, presenting the following results: very clayey texture, containing $73.5 \%$ of clay; $\mathrm{pH}$ in $\mathrm{CaCl}_{2}=5.3 ;$ Pmehlich $=23.3 \mathrm{mg}$ $\mathrm{dm}^{-3} ; \mathrm{K}=0.50 \mathrm{cmole} \mathrm{dm}^{-3} ; \mathrm{Ca}=3.5 \mathrm{cmole} \mathrm{dm}^{-3} ; \mathrm{Mg}=1.03 \mathrm{cmole}^{-3}$ $\mathrm{dm}^{-3} ; \mathrm{Zn}=4.7 \mathrm{mg} \mathrm{dm}^{-3} ; \mathrm{B}=0.30 \mathrm{mg} \mathrm{dm}^{-3} ; \mathrm{Fe}=16 \mathrm{mg} \mathrm{dm}^{-3} ; \mathrm{Cu}=$ $4.0 \mathrm{mg} \mathrm{dm}^{-3} ; \mathrm{Mn}=4.2 \mathrm{mg} \mathrm{dm}^{-3} ; \mathrm{H}+\mathrm{Al}=3.10 \mathrm{cmole} \mathrm{dm}^{-3} ; \mathrm{SB}=$ $5.05 \mathrm{cmole} \mathrm{dm}^{-3} ; \mathrm{T}=8.15 \mathrm{cmole} \mathrm{dm}^{-3} ;$ and $\mathrm{V} \%=52 \%$.

Two months before transplant, the soil acidity of the area was corrected with liming, aiming to increase the base saturation to $70 \%$. After limestone application, the soil was plowed and barred; and two days before transplanting, the beds were raised and fertilization was performed, according to the results of soil analysis and recommendation for the crop (Ribeiro et al., 1999). When the seedlings had three definite leaves they were transplanted to the definitive site.

The fertilization consisted of $150 \mathrm{~kg} \mathrm{ha}^{-1}$ of $\mathrm{N}$ and $50 \mathrm{~kg}$ ha-1 of $\mathrm{P}_{2} \mathrm{O}_{5}$, using as source urea and simple superphosphate, respectively. In planting fertilization, $20 \%$ of $\mathrm{N}$ was used and the total $\mathrm{P}_{2} \mathrm{O}_{5}$ recommended. In cover fertilizers, $20 \%, 30 \%$ and $30 \%$ of the total recommended $\mathrm{N}$ were used, respectively, at 15, 30, and 40 days after transplantation (Ribeiro et al., 1999).

Zinc foliar applications were carried out in a single dose with the aid of a Guarani manual costal pump, with a capacity of 20 liters of syrup, and a volume of 4 liters of syrup for each 16 plots, which corresponded to the point of dripping. The application was performed on May 13, 2018, fifteen days after transplantation (DAT), in the late afternoon. After application, irrigation was stopped for a period of 24 hours. To avoid drift, a $1 \mathrm{~m}$ high plastic curtain was installed around the plot at the time of application.

The irrigation system used was by spraying, with two daily watering shifts, to keep the soil always moist and suitable for the best crop development. Phytosanitary treatments were carried out throughout the crop cycle, according to the incidence of pests and diseases, with registered products. Weeding was done manually to keep the crop always clean.

Harvest was performed at 43 DAT, when the plants showed their maximum vegetative development. Before harvesting, the chlorophyll content of the plants in the useful plot was measured using the Minolta SPAD-502 CFL1030 chlorophyll meter on the median leaf of the plant in the morning. After harvesting, the heads were taken to the Phytotechnic Laboratory (LAFIT) to determine the following traits: plant height $(\mathrm{cm})$, total fresh mass $\left(\mathrm{kg} \mathrm{plant}^{-1}\right)$, stem diameter $(\mathrm{mm})$, head diameter $(\mathrm{cm})$, number of leaves per plant, and estimated average yield $\left(\mathrm{kg} \mathrm{m}^{-2}\right)$. 
The leaf zinc content $\left(\mathrm{mg} \mathrm{kg}^{-1}\right)$ was determined at the Soil Laboratory of the Universidade Federal de Uberlândia - Campus Uberlândia (LABAS). The samples were washed in running water and subsequently in distilled water. They were placed in an oven with forced air circulation at $65{ }^{\circ} \mathrm{C}$ until they reach a constant mass and then ground and subjected to chemical analysis. Zinc leaf contents were determined by nitricperchloric extract by atomic absorption spectrophotometry (Silva, 2009).

For statistical analysis, Shapiro-Wilk, Levene and Tukey tests were used for ANOVA residual normality, homogeneity between variances and block additivity, respectively $(p<0.01)$, using the IBM SPSS Statistics version software 20.0 (Marôco, 2018). Given these assumptions, the data were subjected to analysis of variance by the $F$ test $(p<0.05)$ and, when there were significant effects, the averages of the cultivar factor were compared by the Tukey test $(p<0.05)$ using the SISVAR program $^{\circ}$ (Ferreira, 2008). For the dose factor, regression analysis was performed using the statistical software Sigma Plot $^{\circledR}$ version 14 (Systat Software Inc, 2008).
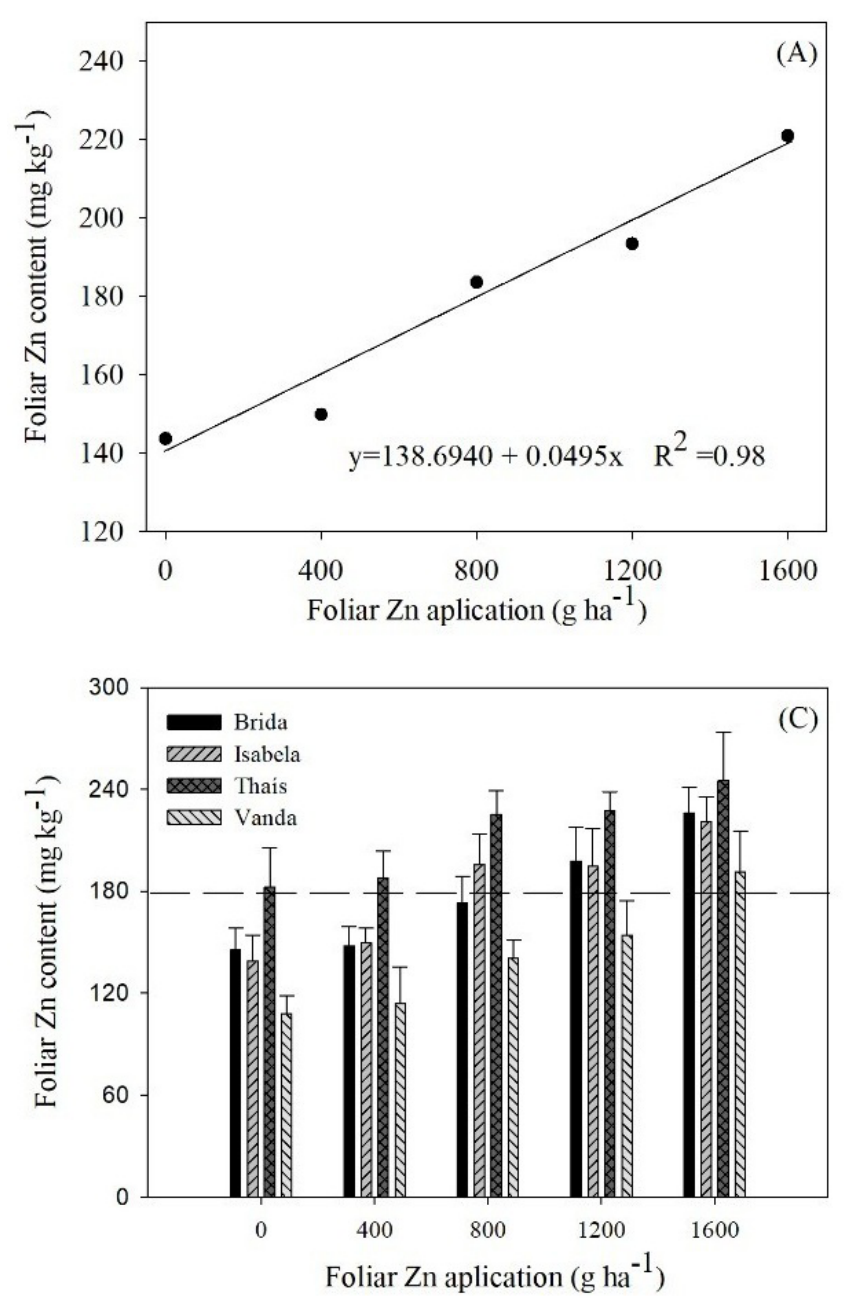

\section{Results and Discussion}

\section{Biofortification with zinc of curly lettuce cultivars}

The leaf zinc content of curly lettuce was influenced by cultivar and doses; however, no significant interaction was verified among these factors (Figure 1). Higher rates of zinc application promote linear increases in the leaf zinc content, with an increment rate of $0.049 \mathrm{mg} \mathrm{kg}^{-1}$ of zinc leaf for each zinc gram ( $\mathrm{g} \mathrm{ha}^{-1}$ ) applied (Figure $1 \mathrm{~A}$ ). In addition, the cv. Thaís responded with greater $\mathrm{Zn}$ content in the leaf tissue, presenting an average content of $213 \mathrm{mg} \mathrm{kg}^{-1}$ (Figure 1B). However, the cv. Vanda presented lower $\mathrm{Zn}$ content (141 $\left.\mathrm{mg} \mathrm{kg}^{-1}\right)$. Thaís had $51 \%$ more leaf zinc content than cv. Vanda (Figure $1 \mathrm{~B}$ ).

According to the USDA (2019), the average leaf Zn content in lettuce is $180 \mathrm{mg} \mathrm{kg}^{-1}$. Based on this value, the $\mathrm{cv}$. Thais has higher leaf zinc content in all doses of zinc used, and this cultivar also had the highest responses to increasing doses (Figure 1C). The cultivars Brida and Isabela responded with increments above the reference value when the doses of 1200 and $1600 \mathrm{~g} \mathrm{ha}^{-1}$ were used.
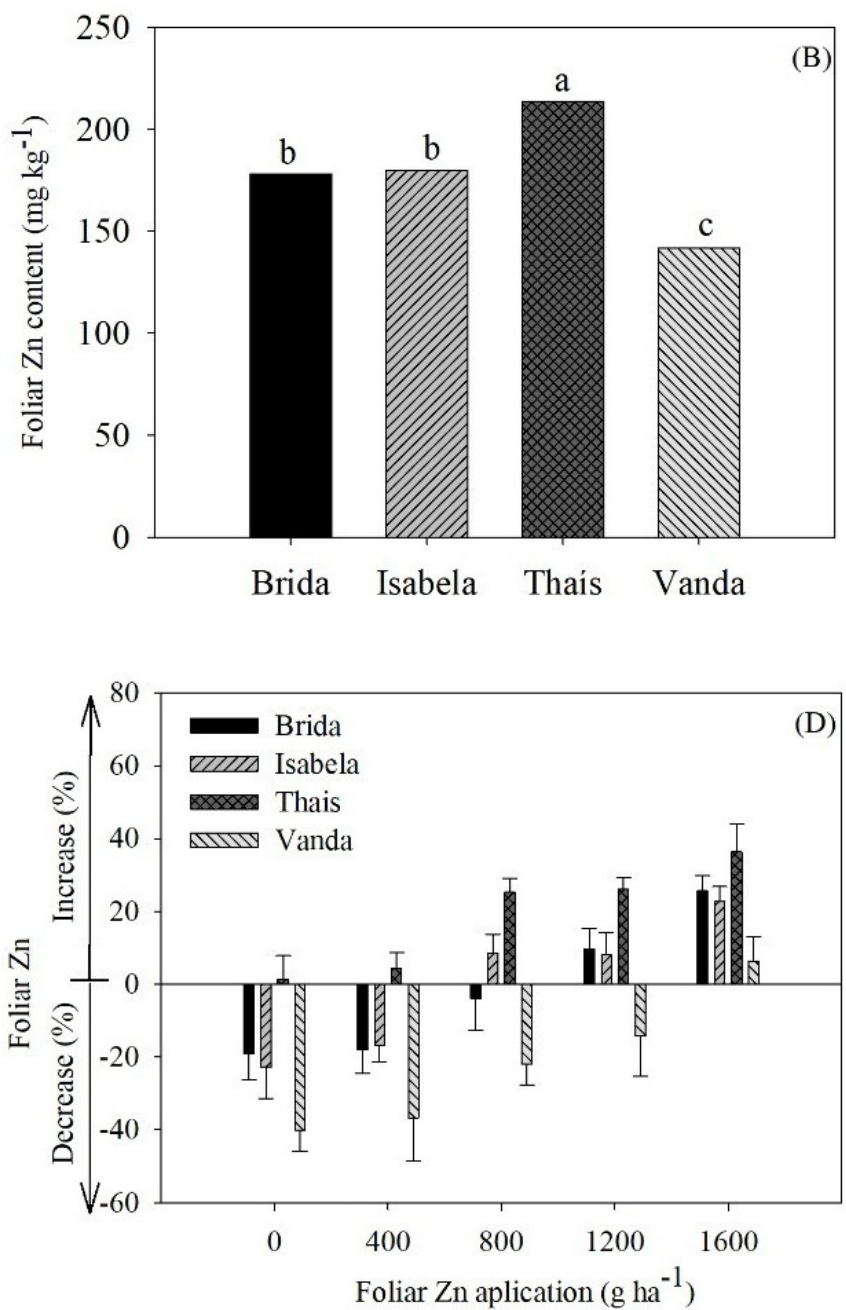

Figure 1. (A) Leaf zinc content in curly lettuce as a function of increasing doses of zinc via leaf; (B) Average leaf zinc content in curly lettuce cultivars (different letters on the bars indicate difference between the means by Tukey test $(p<0.05)$; $(C)$ Mean leaf zinc content as a function of cultivars and doses, with their respective standard deviations. Dashed line indicates zinc reference value in lettuce leaves (180 mg kg-1 - USDA, 2019); (D) Change of leaf zinc content from the reference value (180 mg kg-1 - USDA, 2019). 
The relative increments of leaf zinc for each cultivar at all evaluated doses are shown in Figure 1D, based on the reference value of $180 \mathrm{mg} \mathrm{kg}^{-1}$. It is verified that at the zinc dose of $1600 \mathrm{~g} \mathrm{ha}^{-1}$ all cultivars presented leaf zinc content higher than the reference, especially cv. Thais showed an average increase of $36 \%$. In the highest dose, the cultivars Brida, Isabela, and Vanda presented average increments of 25,22 and $6 \%$, respectively. It is noteworthy that at the dose of $800 \mathrm{~g} \mathrm{ha}^{-1}$ from zinc to $\mathrm{cv}$. Thaís presented a significant increase of $25 \%$, that is, with half of the maximum dose used, this cultivar showed satisfactory response to biofortification. The cv. Vanda had lower zinc content in leaf tissue compared to the other cultivars and reference value.

These results demonstrate the high agronomic biofortification potential of zinc curly lettuce, since significant increases of leaf zinc were obtained in the cultivars and doses used. Considering the content of zinc in the leaf tissue, it can be said that all cultivars reached levels that made them biofortified, besides, the zinc content is within the limit that can be consumed by people without harm to health (25$250 \mathrm{mg} \mathrm{kg}^{-1}$ ) (Martinez et al., 1999). However, one must pay attention to the results of agronomic traits, so that there is no productive damage.

Agronomic traits of curly lettuce submitted to zinc biofortification

There was significant interaction between cultivars and doses of zinc for plant height, SPAD index, total fresh mass and average yield (Table 1). Plant height ranged from $15.76 \mathrm{~cm}$ (cv. Brida at a dose of $0 \mathrm{~g} \mathrm{ha}^{-1}$ ) to $19.58 \mathrm{~cm}$ (cv. Vanda at a dose of $800 \mathrm{~g} \mathrm{ha}^{-1}$ ). In general, the highest values were obtained for the cv. Thaís, except at the dose of $800 \mathrm{~g} \mathrm{ha}^{-1}$, in which it did not differ from the others.

Plant height of lettuce cultivars presented quadratic polynomial adjustment with increasing $\mathrm{Zn}$ doses (Figure $2 \mathrm{~A}$ ), with the application of $812,632,703$, and $737 \mathrm{~g} \mathrm{ha}^{-1}$ (maximum curve point) resulted in the highest plant height for the cultivars Brida, Isabela, Thaís, and Vanda, respectively. These doses promoted increases of $20.3,7.9,5.9$, and $16.2 \%$ in plant height for cultivars Brida, Isabela, Thaís, and Vanda, respectively. This result indicates that zinc may aid both production and biofortification, as it is a component of growth hormones, such as auxins, which are directly linked to plant development (Brennan, 2005).

These data corroborate with data obtained by Reyes et al. (2019), who applied zinc in a single dose via arugula leaf for biofortification, despite observing phytotoxic effects on plants between 1 to $1.5 \mathrm{~kg} \mathrm{ha}^{-1}$ did not show a decrease in productivity. The values found in the current experiment are close to the values found by other authors (Silveira et al., 2015; Vargas et al., 2017). Thus, the biofortified plants obtained in this study have standard height and are acceptable to the consumer market, that is, plants whose harvest point was not exceeded and, consequently, that were not clogged. In this sense, agronomic biofortification can increase the nutritional
Table 1. Plant height, SPAD index, total fresh mass, and yield of four curly lettuce cultivars as a function of foliar zinc doses.

\begin{tabular}{|c|c|c|c|c|c|}
\hline \multirow{2}{*}{ Cultivar } & \multicolumn{5}{|c|}{ Doses of $\mathrm{Zn}\left(\mathrm{g} \mathrm{ha}^{-1}\right)$} \\
\hline & 0 & 400 & 800 & 1200 & 1600 \\
\hline & \multicolumn{5}{|c|}{ Plant height $(\mathrm{cm})$} \\
\hline Brida & $15.76 \mathrm{~b}$ & $18.14 b$ & $19.46 \mathrm{a}$ & $17.73 a b$ & $16.19 \mathrm{~b}$ \\
\hline Isabela & $17.58 \mathrm{a}$ & $18.90 \mathrm{ab}$ & $19.13 \mathrm{a}$ & $17.56 \mathrm{ab}$ & $15.88 \mathrm{~b}$ \\
\hline Thaís & $18.20 \mathrm{a}$ & $19.32 \mathrm{a}$ & $19.48 \mathrm{a}$ & $18.50 \mathrm{a}$ & $17.72 \mathrm{a}$ \\
\hline Vanda & $16.34 \mathrm{~b}$ & $19.27 \mathrm{a}$ & $19.58 \mathrm{a}$ & $17.38 \mathrm{~b}$ & $16.02 \mathrm{~b}$ \\
\hline MSD & 0.98 & & & & \\
\hline CV (\%) & 2.93 & & & & \\
\hline \multicolumn{6}{|c|}{ Index SPAD } \\
\hline Brida & 20.17 a & $20.31 \mathrm{a}$ & $20.32 \mathrm{ab}$ & $21.15 \mathrm{a}$ & $22.00 \mathrm{a}$ \\
\hline Isabela & $17.54 \mathrm{~b}$ & $20.76 \mathrm{a}$ & $21.15 \mathrm{a}$ & $21.54 \mathrm{a}$ & $22.50 \mathrm{a}$ \\
\hline Thaís & $15.21 \mathrm{C}$ & $15.77 c$ & $15.98 \mathrm{C}$ & $16.32 \mathrm{c}$ & $18.42 b$ \\
\hline Vanda & $18.25 \mathrm{a}$ & $18.77 b$ & $19.17 b$ & $19.52 \mathrm{~b}$ & $19.67 b$ \\
\hline MSD & 1.49 & & & & \\
\hline CV (\%) & 4.14 & & & & \\
\hline \multicolumn{6}{|c|}{ Total fresh mass $\left(\mathrm{kg} \mathrm{plant}^{-1}\right)$} \\
\hline Brida & $0.25 a b$ & $0.26 \mathrm{a}$ & $0.23 \mathrm{~b}$ & $0.21 \mathrm{ab}$ & $0.20 \mathrm{a}$ \\
\hline Isabela & $0.22 \mathrm{~b}$ & $0.24 \mathrm{a}$ & $0.24 a b$ & $0.22 a b$ & $0.21 \mathrm{a}$ \\
\hline Thaís & $0.25 a b$ & $0.27 \mathrm{a}$ & 0.28 a & $0.19 \mathrm{~b}$ & $0.17 \mathrm{a}$ \\
\hline Vanda & 0.27 a & $0.25 \mathrm{a}$ & $0.27 \mathrm{ab}$ & $0.24 a$ & $0.21 \mathrm{a}$ \\
\hline MSD & 0.04 & & & & \\
\hline CV (\%) & 9.28 & & & & \\
\hline \multicolumn{6}{|c|}{ Yield $\left(\mathrm{kg} \mathrm{m}^{-2}\right)$} \\
\hline Brida & $4.04 a b$ & $4.13 \mathrm{a}$ & $3.81 \mathrm{~b}$ & $3.35 a b$ & $3.20 \mathrm{a}$ \\
\hline Isabela & $3.54 b$ & $3.88 \mathrm{a}$ & $3.90 \mathrm{ab}$ & $3.59 a b$ & $3.41 \mathrm{a}$ \\
\hline Thaís & $4.08 a b$ & $4.38 \mathrm{a}$ & $4.48 \mathrm{a}$ & $3.01 \mathrm{~b}$ & $2.80 \mathrm{a}$ \\
\hline Vanda & $4.27 \mathrm{a}$ & $4.03 \mathrm{a}$ & $4.29 a b$ & $3.89 a$ & $3.43 \mathrm{a}$ \\
\hline MSD & 0.66 & & & & \\
\hline CV (\%) & 9.28 & & & & \\
\hline
\end{tabular}

(a) MSD = Minimum significant difference; CV (\%) = Coefficient of variation.

(b) Means followed by the same letter in the column do not differ from each other by Tukey's test at $5 \%$ significance level.

value of lettuce without compromising the characteristics required by consumers.

Analysis of chlorophyll content in leaves is a method used to monitor plant development, providing information on physiological state, nitrogen levels in leaves, and photosynthetic potential of plants (Riccardi et al., 2014; Yang et al., 2014). The SPAD index is an indirect measure of chlorophyll content in leaves because it correlates with chlorophyll content and nutritional status of plants. The SPAD index values ranged from 15.21 (cv. Thaís when no zinc was applied via leaf) to 22.50 (cv. Isabela when $1600 \mathrm{~g} \mathrm{ha}^{-1}$ of $\mathrm{Zn}$ was applied via leaf) (Table $1)$. Linear increase in SPAD index values was observed at each $1 \mathrm{~g} \mathrm{ha}^{-1}$ increase in zinc doses, regardless of cultivar (Figure 2B). This can be reflected in excellent quality leaves, as found by Cassetari et al. (2015), since chlorophyll content is directly related to photosynthetic activity and plant nutritional status.

Some authors (Kaya \& Higgs, 2001; Anwaar et al., 2015; Roosta et al., 2018) reported that the decrease in chlorophyll content may be caused by both zinc deficiency and toxicity. Because, zinc is directly involved with the process of photosynthesis, nitrogen metabolism, respiration, and protein synthesis in plants (Malavolta, 2006; Cardoso et al., 2012; Mascarenhas et al., 2014). 

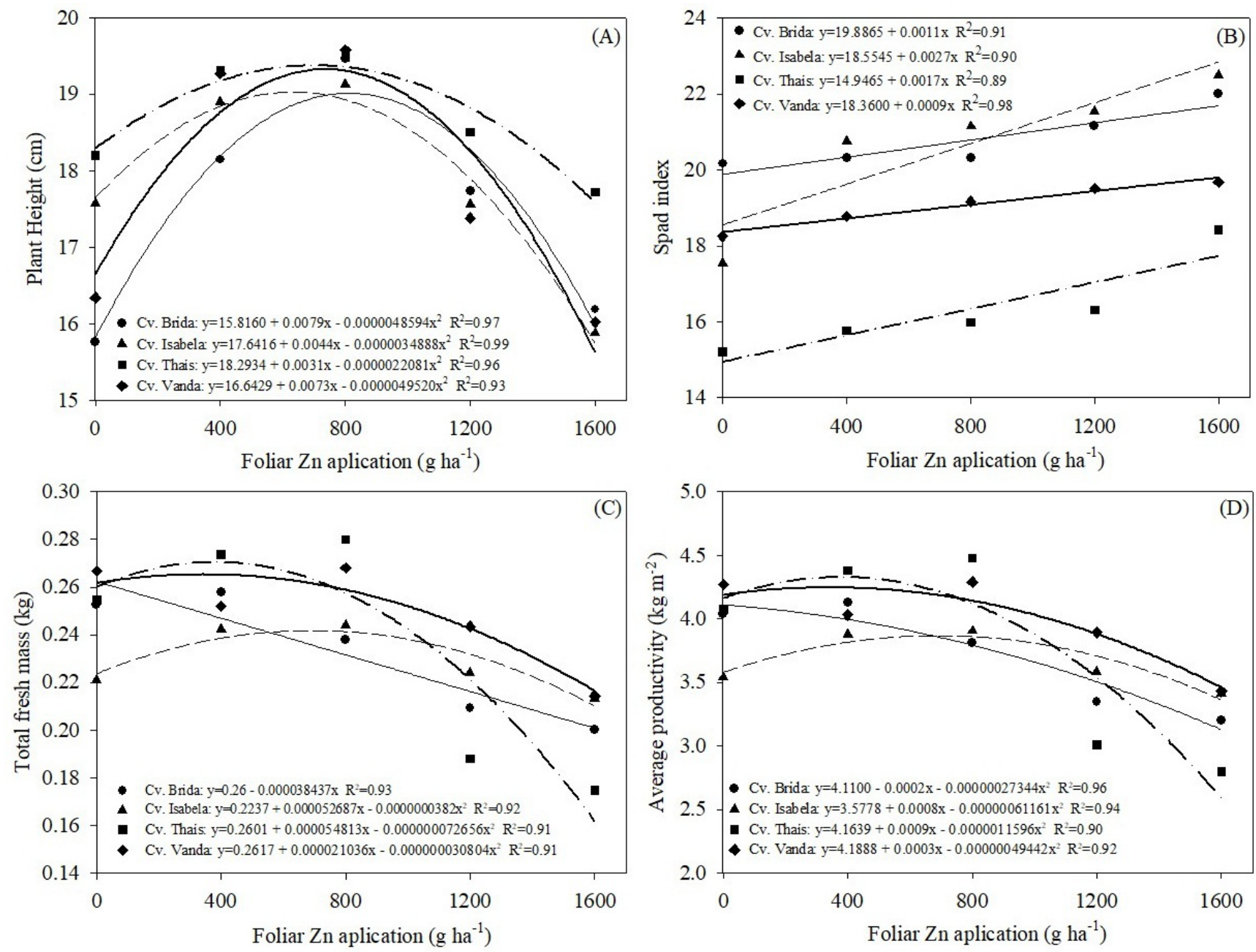

Figure 2. (A) Plant height, (B) SPAD index, (C) total fresh mass, and (D) average yield of the four curly lettuce cultivars as a function of zinc doses.

The cultivar Thaís had more $\mathrm{Zn}$ absorption, hence more $\mathrm{Zn}$ content in the leaves (Figure 1B). In the other hand, this cultivar showed reduction in the fresh weight on higher doses of $\mathrm{Zn}$ (Figure 2C). Fresh masses of $\mathrm{cv}$. Thaís ranged from 0.16 $\mathrm{kg}$ when $1600 \mathrm{~g} \mathrm{ha}^{-1}$ zinc was applied to $0.25 \mathrm{~kg}$ when 800 $\mathrm{g} \mathrm{ha}^{-1}$ was applied (Figure 2C). The application of $1600 \mathrm{~g} \mathrm{ha}^{-1}$ zinc reduced $64 \%$ the fresh weight of $\mathrm{cv}$. Thais in relation to $800 \mathrm{~g} \mathrm{ha}^{-1}$ dose of $\mathrm{Zn}$. This reduction could be related to phytotoxicity due application of higher rates of $\mathrm{Zn}$.

Although, $\mathrm{Zn}$ is an essential micronutrient it could affect the growth and plant metabolism when this element is present in the environment in toxic levels (Marschner, 1995). Only the cultivar Thais were able to accumulate more than 200 $\mathrm{mg} \mathrm{kg}^{-1}$ of Zn (Figure 1B). According to Martinez et al. (1999) the ideal content of $\mathrm{Zn}$ for lettuce range from 25 to $250 \mathrm{mg}$ $\mathrm{kg}^{-1}$, whereas for Trani \& Raij (1997) it would be between 30 and $100 \mathrm{mg} \mathrm{kg}^{-1}$. Therefore, high doses of $\mathrm{Zn}$ could affect plant growth due phytotoxicity. In this study, for all tested cultivars, the least fresh weight was observed when the highest $\mathrm{Zn}$ dose was applied (Figure 2C).

According to Yuri et al. (2006), the largest fresh mass of iceberg lettuce, was found when $2.01 \mathrm{~kg} \mathrm{ha}^{-1}$ of zinc sulfate was applied via leaf, differing from the current experiment, where the largest fresh mass was found at doses of 663.98, 425.90, and $277.78 \mathrm{~g} \mathrm{ha}^{-1}$ for cultivars Isabela, Thaís and Vanda, respectively (Figure $2 \mathrm{C}$ ). For cv. Brida, there was a decrease of $0.0375 \mathrm{~g}$ in fresh lettuce mass every $1 \mathrm{~g} \mathrm{ha}^{-1}$ of zinc applied (Figure 2C). This difference may have been due to the fact that the soil of the area in which the current experiment was implemented was high in zinc compared to the soil of the place where the experiment by Yuri et al. (2006), which had a low zinc content (1.2 $\mathrm{mg} \mathrm{dm}^{-3}$ zinc). Although the soil of the current experiment was high in zinc, there was a positive response to the total fresh mass of the plants against micronutrient application. Sago et al. (2018) observed drastic reductions in lettuce fresh mass values with increasing zinc content from 0.15 to $0.45 \mathrm{mM}$ in nutrient solution.

The different results found for fresh mass can be justified by the genetic difference among curly lettuce cultivars, which can lead to distinctions in morphological and productive characteristics, even under similar climatic conditions; different sources of mineral fertilizers used, which may or may not facilitate absorption by the leaf cuticle. In addition, due to the split application of the nutrient application, as a single application of zinc via leaf 14 days after transplant may cause 
better utilization of the nutrient by the plant, as observed by Yuri et al. (2006).

For the estimated average yield trait, there was a difference among cultivars at doses of 0,800 and $1200 \mathrm{~g} \mathrm{ha}^{-1}$ of zinc (Table 1). For all cultivars, according to the doses used, there was an adjustment of the quadratic polynomial model. The cultivars Brida, Isabela, Thaís, and Vanda had higher yields at doses of 397.11, 694.44, 389.27, and $305.50 \mathrm{~g} \mathrm{ha}^{-1}$, respectively (Figure 2D). After reaching the maximum doses, yield decreases were observed with increasing leaf zinc doses, regardless of cultivar.

For cv. Vanda, the average yield in this experiment ranged from 42.9 to $34.3 \mathrm{t} \mathrm{ha}^{-1}$; already in the experiment by Resende et al. (2018), the maximum yield obtained for the same cultivar was $49.3 \mathrm{t} \mathrm{ha}^{-1}$. Despite the difference in productivity in both experiments, this is not significant $(14.9 \%$ between the highest yield of the current experiment and the yield found by the author in question), since the main objective, biofortification and, consequently, the availability of the product. nutrient through a low-cost food and easily available to the whole population, has been reached.

For the traits head diameter, stem diameter, number of leaves per plant and leaf zinc content, there was no significant interaction between the evaluated factors. Thus, for these trits, cultivars and zinc doses were evaluated separately (Table 2). The values for head diameter were from 27.90 to $28.43 \mathrm{~cm}$, not statistically different among cultivars (Table 2). Because head diameter is a very relevant feature on the part of consumers at the time of lettuce acquisition, leaf application of zinc may be a promising alternative for growers, as it does not interfere with production characteristics and has beneficial to population because it is important for the synthesis and repair of DNA, RNA and proteins, as well as influencing biochemical and physiological processes related to growth, division, cell differentiation, development, and aging (Fukada et al., 2011).

The values for this trait, due to the application of zinc doses via leaf, adjusted to the second-degree polynomial equation, and the largest head diameter $(29.56 \mathrm{~cm})$ was found when the 706 doses was applied $76 \mathrm{~g} \mathrm{ha}^{-1}$ zinc (Figure 3).

Because the packaging of leafy vegetables for later transport is done in plastic or wooden boxes, traits such as head diameter and plant height are of great importance (Sala \& Costa, 2012). However, despite the relentless pursuit by producers of larger plants, this is not always beneficial as larger plants are the most damaged in packaging and transport

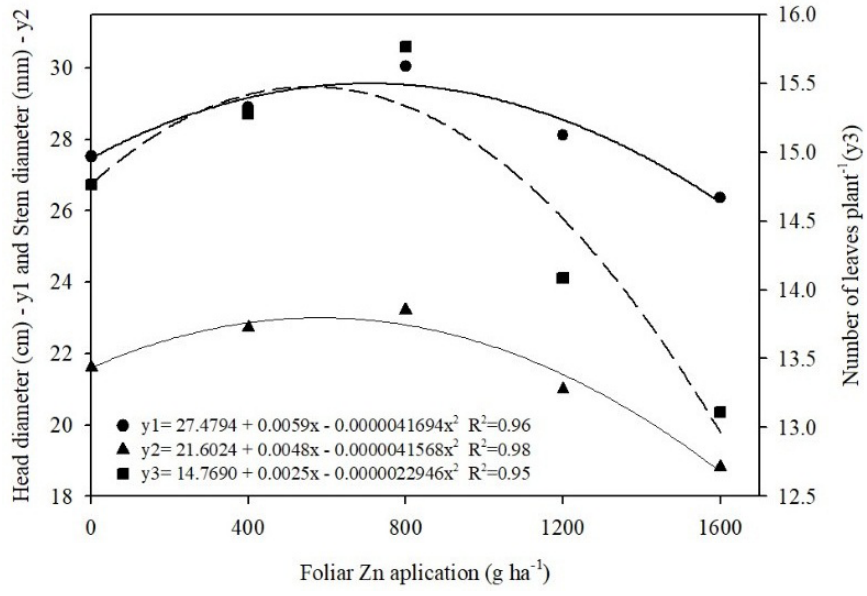

Figure 3. (y1) Head diameter (cm), (y2) stem diameter (mm), and $(\mathrm{y} 3)$ number of leaves plant ${ }^{-1}$ as a function of zinc doses.

processes, thus reducing the commercial quality of the final product (Suinaga et al., 2013).

Regarding the stem diameter, it was possible to verify that the cv. Vanda differed from the others, with an average of $24.15 \mathrm{~mm}$ (Table 2). The values for these traits, as a function of the different doses of leaf zinc, regardless of the cultivar evaluated, were adjusted to the second-degree polynomial equation, and the $577.41 \mathrm{~g} \mathrm{ha}^{-1}$ dose provided the largest stem diameter. with $22.98 \mathrm{~mm}$ (Figure 3).

The number of leaves in the current experiment ranged from 12.31 to 16.32 leaves plant ${ }^{-1}$, and $\mathrm{cv}$. Vanda differed statistically from the others, with higher number of leaves (Table 2). The dose of $545.85 \mathrm{~g} \mathrm{ha}^{-1}$ zinc reflected in the largest number of leaves (15.45 leaves plant ${ }^{-1}$ ), regardless of cultivar. From this dose, there was a decrease in the number of leaves with the increase of the applied dose (Figure 3).

The number of leaves is an extremely important traits, due to the fact that the leaves constitute the commercial part of lettuce (Filgueira, 2008) and the consumer's attention at the moment of purchase is focused on the appearance, volume and indirectly to the number of leafs. In addition, the number of leaves contained in each plant may indicate the adaptation of genetic material to the environment (Diamante et al., 2013), especially to temperature, photoperiod (Oliveira et al., 2004) and the management employed in the crop.

Zinc Doses higher than $545.85 \mathrm{~g} \mathrm{ha}^{-1}$ caused a reduction in the number of leaves (Figure 3), probably due to phytotoxicity

Table 2. Head diameter $(\mathrm{cm})$, stem diameter $(\mathrm{mm})$, number of leaves per plant, and leaf zinc content of four curly lettuce cultivars as a function of different doses of zinc.

\begin{tabular}{ccccc}
\hline Cultivar & $\begin{array}{c}\text { Head diameter } \\
(\mathbf{c m})\end{array}$ & $\begin{array}{c}\text { Stem diameter } \\
(\mathbf{m m})\end{array}$ & $\begin{array}{c}\text { Number } \\
\text { of leafs }\end{array}$ & $\begin{array}{c}\text { Zinc leaf content } \\
(\mathbf{m g ~ k g})^{-1}\end{array}$ \\
\hline Brida & $27.90 \mathrm{a}$ & $21.28 \mathrm{~b}$ & $15.54 \mathrm{~b}$ & $177.95 \mathrm{~b}$ \\
Isabela & $28.43 \mathrm{a}$ & $20.01 \mathrm{~b}$ & $14.24 \mathrm{c}$ & $179.95 \mathrm{~b}$ \\
Thaís & $28.43 \mathrm{a}$ & $20.46 \mathrm{~b}$ & $12.31 \mathrm{~d}$ & $213.66 \mathrm{a}$ \\
Vanda & $28.01 \mathrm{a}$ & $24.15 \mathrm{a}$ & $16.32 \mathrm{a}$ & $141.65 \mathrm{c}$ \\
MSD & 0.61 & 1.70 & 0.51 & 14.62 \\
CV (\%) & 2.58 & 9.46 & 4.18 & 9.80 \\
\hline
\end{tabular}

(a) MSD = Minimum significant difference; CV (\%) = Coefficient of variation.

(b) Means followed by the same letter in the column do not differ from each other by Tukey's test $(p \geq 0.05)$. 
caused by high leaf $\mathrm{Zn}$ content obtained in the highest doses evaluated (Figure 1A). Other studies (Queiroz et al. 2014; Nespoli et al. 2017) reported a higher number of leaves than the present study. Although the plant size influences the choice of the consumer market, the search for a healthier lifestyle is increasingly part of the routine of Brazilians. According to Euromonitor International (2017), the healthy food and beverage market in Brazil has grown over the last five years by an average of $12.3 \%$ per year.

Given this, some factors may have contributed to the results on the productive traits of the crop, in this work, among them, the high zinc content in the soil $\left(4.7 \mathrm{mg} \mathrm{dm}^{-3}\right)$. According to Ribeiro et al. (1999), soils with high zinc content are those with values above $2.2 \mathrm{mg}$ zinc per $\mathrm{dm}^{3}$ of soil. Therefore, the soil in which the experiment was implemented had about $105 \%$ more zinc than the critical level, which may have influenced the development of some lettuce cultivars, since zinc is a micronutrient related to nitrogen metabolism, in addition to growth hormone components, such as auxins, which are directly linked to plant development.

For the leaf zinc content, the cv. Thaís presented the highest micronutrient content in the leaf $\left(231.66 \mathrm{mg} \mathrm{kg}^{-1}\right)$, differing from the other cultivars, with $61.14 \%$ more zinc than the cv. Vanda (Table 2). It can be observed, according to the regression analysis graph, that the zinc rates for leaf zinc adjusted to the growing linear model for all cultivars, and for each 1 gram of zinc applied via leaf, There was an increase of $0.0495 \mathrm{mg} \mathrm{kg}^{-1}$ in the zinc leaf content of lettuce cultivars (Figure 3). Similarly, Sago et al. (2018) observed that the zinc leaf content of lettuce gradually increases as the zinc concentrations in the nutrient solution increase. Seema et al. (2017), in a study with spinach, also observed that leaf zinc content increased as there was an increase in zinc content applied to the soil. According to Reyes et al. (2019), foliar fertilization with up to $1.5 \mathrm{~kg} \mathrm{ha}^{-1}$ of zinc, even when applied in soils with high micronutrient content, does not affect the physiological parameters and biomass of arugula.

According to WHO (2006), the tolerable daily intake limit of zinc for an adult is $21-70 \mathrm{mg}$ and cannot exceed this limit due to micronutrient toxicity. The daily intake indicated in the US according to the ICZ (2019) is 12 and $15 \mathrm{mg} \mathrm{day}^{-1}$, respectively, for women and men, and pregnant and lactating women need $19 \mathrm{mg} \mathrm{day}^{-1}$. Thus, considering the amounts of zinc found in the cultivars evaluated in the current experiment and how crisp lettuce already participates in the composition of Brazilian daily meals, in the form of salads, such vegetables would contribute part of the nutritional needs required by humans daily.

In order to supply the daily nutrient requirement by the human body (average of $15 \mathrm{mg} \mathrm{day}^{-1}$ in adult men), the necessary consumption of lettuce of cultivars Brida, Isabela, Thaís and Vanda would be 84.29, respectively; 83.36, 70.20, and $105.90 \mathrm{~g}$ day $^{-1}$. Adequate zinc fertilization is an important factor for lettuce cultivation, since in addition to increasing zinc concentration, reducing $\mathrm{NO}_{3}$ levels and increasing the concentration of essential amino acids, all with beneficial properties for human nutrition
(Barrameda-Medina et al., 2016). Zinc is found in many foods, including beef, oysters, almonds, Brazil nuts, liver, mollusks, eggs, soy flour (TACO, 2011). However, these sources of zinc may not be accessible to low-income people. Thus, biofortification of leafy vegetables such as curly lettuce is a good alternative to supply nutritional deficiency.

\section{Conclusions}

The curly lettuce cv. Thaís had the highest leaf zinc content and can be considered the most biofortified, while cv. Vanda did not show satisfactory responses with the different doses of leaf zinc applied.

The use of $700 \mathrm{~g} \mathrm{ha}^{-1}$ of leaf zinc is recommended to obtain biofortified lettuce with yield increase.

\section{Acknowledgements}

We are grateful for research support from the Lettuce breeding program at the Universidade Federal de Uberlândia, and for financial support from the Brazilian CAPES (Finance Code 001), CNPq and FAPEMIG institutions.

\section{Literature cited}

Almendros, P.; Obrador, A.; Gonzales, D.; Alvarez, J. M. Biofortification of zinc in onions (Allium cepa L.) and soil $\mathrm{Zn}$ status by the application of different organic $\mathrm{Zn}$ complexes. Scientia Horticulturae, v. 186, p. 254-265, 2015. https://doi. org/10.1016/j.scienta.2015.02.023.

Anwaar, S. A.; Ali, S.; Ishaque, W.; Farid, M.; Farooq, M. A.; Najeeb, U.; Abbas, F.; Sharif, M. Silicon (Si) alleviates cotton (Gossypium hirsutum $\mathrm{L}$.) form zinc ( $\mathrm{Zn}$ ) toxicity stress by limiting $\mathrm{Zn}$ uptake and oxidative damage. Environmental Science and Pollution Research, v. 22, n. 5, p. 3441-3450, 2015. https://doi.org/10.1007/s11356014-3938-9.

Barrameda-Medina, Y.; Lentini, M.; Esposito, S.; Ruiz, J. M.; Blasco, B. Zn-biofortification enhanced nitrogen metabolism and photorespiration process in green leafy vegetable Lactuca sativa L. Journal of the Science of Food and Agriculture, v. 97, n.6, p. 1828-1836, 2016. https://doi.org/10.1002/jsfa.7983.

Brennan, R. F. Zinc application and Its availability to plants. Perth: Murdoch University, 2005. 258p. Doctoral Thesis. https://core. ac.uk/download/pdf/11231072.pdf. 29 Mar. 2020.

Cakmak, I. Enrichment of cereal grains with zinc: agronomic or genetic biofortification. Plant and Soil., v. 302, n. 1, p. 1-17, 2008. https://doi.org/10.1007/s11104-007-9466-3.

Cakmak, I. Enrichment of fertilizers with zinc: an excellent investment for humanity and crop production in India. Journal of Trace Elements in Medicine and Biology, v. 23, n. 4, p. 281-289, 2009. https://doi.org/10.1016/j.jtemb.2009.05.002.

Cakmak, I.; Kalayci, M.; Kaya, Y.; Torun, A. A.; Aydin, N.; Wang, Y.; Arisoy, Z.; Erdem, H.; Yazici, A.; Gokmen, O.; Ozturk, L.; Horst, W. J. Biofortification and localization of zinc in wheat grain. Journal of Agricultural and Food Chemistry, v. 58, n. 16, p. 9092-9102, 2010. https://doi.org/10.1021/jf101197h. 
Cambraia, T. L. L. Biofortificação agronômica do feijão pelo manejo da adubação com Zn. Viçosa: Universidade Federal de Viçosa, 2015. 47p. Dissertação Mestrado. https://www.locus.ufv. $\mathrm{br} /$ bitstream/handle/123456789/6460/texto\%20completo. pdf? sequence=1\&isAllowed=y. 19 Mar. 2020.

Cardoso, E. D.; Haga, K. I.; Binotti, F. F. S.; Filho, W. V. V.; Nogueira, D. C. Doses de zinco e nitrogênio na produtividade e qualidade de grãos de ervilha. Pesquisa Agropecuária. Tropical, v. 42, n. 3, p. 263-271, 2012. https://doi.org/10.1590/S198340632012000300005.

Carvalho, S. M.; Vasconcelos, M. M. Producing more with less: strategies and novel technologies for plant-based food biofortification. Food Research International, v. 53, n. 1, p. 961971, 2013. https://doi.org/10.1016/j.foodres.2012.12.021.

Cassetari, L. S.; Gomes, M. S.; Santos, D. C.; Santiago, W. D.; Andrade, J.; Guimarães, A.C.; Souza, J.A.; Cardoso, M. G.; Maluf, W. R.; Gomes, L. A. $\beta$-Carotene and chlorophyll levels in cultivars and breeding lines of lettuce. Acta Horticulturae, Lisboa, v. 1083, p. 469-474, 2015. https://doi.org/10.17660/ActaHortic.2015.1083.60

Diamante, M. S.; Júnior, S. S.; Inagaki, A. M.; Silva, M. B.; Dallacort, R. Produção e resistência ao pendoamento de alfaces tipo lisa cultivadas sob diferentes ambientes. Revista Ciência Agronômica, v. 44, n. 1, p. $133-140,2013$. https://doi.org/10.1590/S180666902013000100017.

Euromonitor International Brasil. Consumer lifestyles in Brazil 2017. https://www.euromonitor.com/brazil. 15 Apr. 2019.

Ferreira, D. F. Sisvar: um programa para análises e ensino de estatística. Revista Symposium, v. 6, n. 1, p. 36-41, 2008. http://www.dex.ufla. br/ danielff/meusarquivospdf/art63.pdf. 01 Apr. 2020.

Filgueira, F. A. R. Manual de olericultura: cultura e comercialização de hortaliças. 3.ed. Viçosa: Universidade Federal de Viçosa, 2008. 421p.

Fukada, T.; Yamasaki, S.; Nishida, K.; Murakami, M.; Hirano, T. Zinc homeostasis and signaling in health and diseases. Journal of Biological Inorganic Chemistry, v. 16, n. 7, p. 1123-1134, 2011. https://doi.org/10.1007/s00775-011-0797-4.

Graham, R. D.; Welch, R. M.; Saunders, D. A.; Ortiz-Monasterio, I.; Bouis, H. E.; Bonierbale, M.; Haan, S.; Burgos, G.; Thiele, G.; Liria, R.; Meisner, C. A.; Beeber, S. E.; Potts, M. J.; Kadian, M.; Hobbs, P. R.; Gupta, R. K.; Twomlow, S. Nutritious subsistence food systems. In: Sparks, D. L. (Ed.). Advances in Agronomy. London: Academic Press, 2007. v. 92, p. 1-74. https://doi.org/10.1016/ S0065-2113(04)92001-9.

Hotz, C.; Brown, K. H. Assessment of the risk of zinc deficiency in populations and options for its control. Food and Nutrition Bulletin, v. 25, n. 1, p. 91-204, 2004. https://doi.org/10.1177/1 5648265040251 S205.

Hussain, S.; Miyai, T.; Fujishiro, H.; Kawamura, M.; Yasuda, T.; Hijikata, A.; Bin, B.; Irié, T.; Tanaka, J.; Atsumi, T.; Murakami, M.; Nakayama, M.; Ohara, O.; Himeno, S.; Yoshida, H.; Koseki, H.; Ikawa, T.; Mishima, K.; Fukada, T. Biofortification and estimated human bioavailability of zinc in wheat grains as influenced by methods of zinc application. Plant and Soil, v. 361, p. 279-290, 2012. https://doi.org/10.1007\%2Fs11104-012-1217-4.

Instituto de Metais Não Ferrosos - ICZ. O zinco e a saúde. São Paulo: Instituto de Metais não Ferrosos - ICZ, 2019. http://www.icz.org. br/zinco-saude.php. 23 Dec. 2019.
Kaya, C.; Higgs, D. Inter-relationship between zinc nutrition, growth parameters, and nutrient physiology in a hydroponically grown tomato cultivar. Journal of Plant Nutrition, v. 24, n. 10, p. 14911503, 2001. https://doi.org/10.1081/PLN-100106016.

Malavolta, E. Funções dos macro e micronutrientes. In: Malavolta, E. (Ed.). Manual de nutrição mineral de plantas. São Paulo: Agronômica Ceres, 2006. p. 126-162.

Marôco, J. Análise estatística com o SPSS statistics. 7.ed. Pêro Pinheiro: Report Number, 2018. 1013p.

Marschner, H. Mineral nutrition of higher plants. 2.ed. San Diego: Academic, 1995. 902 p.

Martinez, H. E. P.; Carvalho, J. G.; Souza, R. B. Diagnose Foliar. In: Ribeiro, A. C.; Guimarães, P. T. G.; Alvarez V, V. H. Recomendações para o uso de corretivos e fertilizantes em Minas Gerais - 5a Aproximação. Viçosa: Comissão de Fertilidade do Solo do Estado de Minas Gerais, 1999. p. 143-168.

Mascarenhas, H. A. A.; Esteves, J. A. S.; Wutke, E. B.; Gallo, P. B. Micronutrientes em soja no estado de São Paulo. Nucleus, v. 11, n. 1, p. 323-342, 2014. https://doi.org/10.3738/1982.2278.1102.

National Institutes of Health - NIH. Health information. Zinc, fact sheet for health professionals. Rockville: Department of Health e Human Services, 2020. https://ods.od.nih.gov/factsheets/ZincHealthProfessional. 15 Mar. 2020.

Nespoli, A.; Seabra Júnior, S.; Dallacort, R.; Purquerio, L. F. V. Consórcio de alface e milho verde sobre cobertura viva e morta em plantio direto. Horticultura Brasileira, v. 35, n.3, p. 453-457, 2017. https://doi.org/10.1590/s0102-053620170323.

Oliveira, A. C. B.; Sediyama, M. A. N.; Pedrosa, M. W.; Garcia, N. C. P.; Garcia, S. L. R. Divergência genética e descarte de variáveis em alface cultivada sob sistema hidropônico. Acta Scientiarum: Agronomy, v. 26, n.2, p. 211-217, 2004. https://doi.org/10.4025/ actasciagron.v26i2.1894.

Queiroz, J. P. S.; Costa, A. J. M.; Neves, L. G.; Seabra Junior, S.; Barelli, M. A. A. Estabilidade fenotípica de alfaces em diferentes épocas e ambientes de cultivo. Revista Ciência Agronômica, v. 45 , n. 2, p. 276-283, 2014. https://doi.org/10.1590/S180666902014000200007.

Resende, G. M.; Yuri, J. E.; Costa, N. D. Cultivo de alface crespa no Submédio do Vale do São Francisco. Petrolina: Embrapa Semiárido, 2018. 4p. ((Embrapa Semiárido. Instruções técnicas, 134). http://ainfo.cnptia.embrapa.br/digital/bitstream/ item/177804/1/INT134.pdf. 10 Apr. 2020.

Reyes, S. M. R.; Cecílio Filho, A. B.; Aguilar, M. A. L.; Silva, P. H. S. Foliar application of zinc in the agronomic biofortification of arugula. Food Science and Technology, v. 39, n. 4, p. 1011-1017, 2019. http://doi.org/10.1590/fst.12318.

Ribeiro, A. C.; Guimarães, P. T. G.; Alvarez, V. H. V. Recomendações para uso de corretivos e fertilizantes em Minas Gerais - 5a Aproximação. Viçosa: Comissão de Fertilidade do Solo do Estado de Minas Gerais, 1999. 359p.

Riccardi, M.; Mele, G.; Pulvento, C.; Lavini, A.; D’andria, R.; Jacobsen, S. E. Non-destructive evaluation of chlorophyll content in quinoa and amaranth leaves by simple and multiple regression analysis of RGB image components. Photosynthesis Research, v. 120, n. 3, p. 263-272, 2014. https://doi.org/10.1007/s11120-014-9970-2. 
Rios, S. A.; Alves, K. R.; Costa, N. M. B.; Martino, H. S. D. Biofortificação: culturas enriquecidas com micronutrientes pelo melhoramento genético. Revista Ceres, v. 56, n.6, p. 713-718, 2009. http://www.ceres. ufv.br/ojs/index.php/ceres/article/view/3489/1383. 09 Apr. 2020.

Roosta, H. R.; Estaji, A.; Niknam, F. Effect of iron, zinc and manganese shortage induced change on photosynthetic pigments, some osmoregulators and chlorophyll fluorescence parameters in lettuce. Photosynthetica, v. 56, n.2, p. 606-615, 2018. https://doi. org/10.1007/s11099-017-0696-1.

Sago, Y.; Watanabe, N.; Minami, Y. Zinc biofortification of hydroponic baby leaf lettuce grown under artificial lighting with elevated wind speed and root zone temperature. Journal of Agricultural Meteorology, v. 74, n. 4, p. 173-177, 2018. https://doi.org/10.2480/agrmet.D-17-00048.

Sala, F. C.; Costa, C. P. Retrospectiva e tendência da alfacicultura brasileira. Horticultura Brasileira, v. 30, n. 2, p. 187-194, 2012. https://doi.org/10.1590/S0102-05362012000200002.

Seema; M. R.; Yadav, S.; Jatav, S. S.; Meena, R. N.; Kumar, S. Effect of zinc sulphate and organics on zinc content and yield on spinach grown in Inceptisol of Varanasi, India. International Journal of Current Microbiology and Applied Sciences, v. 6, n. 2, p. 473-479, 2017. http://doi.org/10.20546/ijcmas.2017.602.053.

Silva, F. C. Manual de análises químicas de solos, plantas e fertilizantes. 2.ed. Brasília: Embrapa Informação Tecnológica, 2009. 627p.

Silveira, A. L.; Pizolato Neto, A.; Oliveira, A. R. C.; Souza, L. N.; Charlo, H. C. O. Doses de fósforo para a produção de alface americana com e sem aplicação foliar de zinco. Biotemas, v. 28, n. 1, p. 3135, 2015. https://doi.org/10.5007/2175-7925.2015v28n1p31.

Suinaga, F. A.; Boiteux, L. S.; Cabral C. S.; Rodrigues, C. S. Desempenho produtivo de cultivares de alface crespa. Brasília: Embrapa, 2013. 15p. (Embrapa Hortaliças. Boletim de Pesquisa e Desenvolvimento, 89). http://ainfo.cnptia.embrapa.br/digital/ bitstream/item/81571/1/bpd-89.pdf. 09 Apr. 2020.
Systat Software Inc. Sigma Plot for Windows, version 14. 2008. https://sigmaplot.softonic.com.br/. 05 November. 2018.

Tabela Brasileira de Composição de Alimentos - TACO. 4.ed. Campinas: NEPA- UNICAMP, 2011. 161p. https://www.cfn.org. br/wp-content/uploads/2017/03/taco_4_edicao_ampliada_e_ revisada.pdf. 29 Mar. 2020.

Trani, P. E.; Raij, B. V. Hortaliças. In: Raij, B. V.; Cantarella, H.; Quaggio, J. A.; Furlani, A. M. C. (Eds.). Recomendações de adubação e calagem para o Estado de São Paulo. Campinas: Instituto Agronômico \& Fundação IAC, 1997. p.15. (IAC. Boletim técnico, 100).

United States Departament of Agriculture - USDA. National Nutrient Database for Standard Reference Legacy Release. https://ndb. nal.usda.gov/ndb/foods/show/301895. 01 Apr. 2019.

Vargas, P. F.; Zecchini, A. C.; Soares, R. S.; Duarte, L. S.; Silva, E. H. C. Performance of crispy lettuce cultivars in different soil covers. Comunicata Scientiae, v. 8, n. 4, p. 514-520, 2017. https://doi. org/10.14295/cs.v8i4.1942.

World Health Organization - WHO. Evaluation of certain food additives and contaminants: sixty-fourth report of the Joint FAO/ WHO Expert Committee on Food Additives. Geneve: WHO, 2006. 100p. (WHO Technical Report Series, 930). https://bit.ly/35fV29Y. 23 Nov. 2019.

Yang, H.; Yang, J.; Lv, Y.; He, J. SPAD values and nitrogen nutrition index for evaluation of rice nitrogen status. Plant Production Science, $v$. 17, n. 1, p. 81-92, 2014. https://doi.org/10.1626/pps.17.81.

Yuri, J. E.; Resende, G. M.; Mota, J. H.; Souza, R. J.; Carvalho, J. G. 2006. Produção de alface americana, em função de doses e épocas de aplicação de zinco. Ciência e Agrotecnologia, v. 30, n. 4, p. 665-669, 2006. https://doi.org/10.1590/S141370542006000400011 . 